\title{
A Large-Scale Epidemiological Study to Identify Bacteria Pathogenic to Pacific Oyster Crassostrea gigas and Correlation Between Virulence and Metalloprotease-like Activity
}

\author{
Denis Saulnier ${ }^{1,{ }^{*}}$, Sophie De Decker ${ }^{1}$, Philippe Haffner ${ }^{1}$, Laetitia Cobret ${ }^{1}$, Maeva Robert ${ }^{1}$ and \\ Céline Garcia $^{1}$ \\ ${ }^{1}$ Laboratoire de Génétique et Pathologie, IFREMER, BP 33, av. du Mus de Loup, 17390 La Tremblade, France \\ *: Corresponding author : Saulnier D., email address : $\underline{\text { denis.saulnier@ifremer.fr }}$
}

\begin{abstract}
:
A 4-year bacteriological survey (2003-2007) of four molluscs cultivated in France and faced with mortality episodes was performed by the French shellfish pathology network. The more abundant bacteria isolated during 92 mortality episodes, occurring mainly in Pacific oyster Crassostrea gigas, were identified by genotyping methods. It allowed us both to confirm the representativeness of Vibrio splendidus and Vibrio aestuarianus bacterial strains and to identify both a large number of Vibrio harveyi-related strains mainly detected during 2007 oyster mortality outbreaks and to a lesser extent bacterial strains identified as Shewanella colwelliana. Because metalloprotease has been reported to constitute a virulence factor in a few Vibrio strains pathogenic for $C$. gigas, several bacterial strains isolated in this study were screened to evaluate their pathogenicity in C. gigas spat by experimental infection and their ability to produce metalloprotease-like activity in the culture supernatant fluids. A high level (84\%) of concordant results between azocaseinase activities and virulence of strains was obtained in this study. Because bacterial metalloprotease activities appeared as a common feature of pathogenic bacteria strains associated with mortality events of $C$. gigas reared in France, this phenotypic test could be useful for the evaluation of virulence in bacterial strains associated with such mortality episodes.
\end{abstract}




\section{Introduction}

Vibrio are ubiquitous marine bacteria that represent a major source of concern in aquaculture due to the increasing number of strains and species found to be pathogenic for fish and shellfish. Such pathogens can cause severe production losses in the industry. The main aquaculture activity in France is the rearing of Pacific oysters Crassostrea gigas, but it has recurrently suffered large scale summer mortality phenomena over the last 15 years [1]. In particular, $V$. aestuarianus [2, 3] and $V$. splendidus $[4,5]$ have been reported to be associated with summer mortality of oyster spat reared in open sea tidal areas and, to a lesser extent, in older animals [6]. Some bacterial isolates related to these Vibrio species were demonstrated to be pathogenic to $C$. gigas under experimental conditions $[3,5,7]$. Despite these findings, the aetiology of summer mortalities seems to be multifactorial, arising as a result of complex interactions between the physiological and/or genetic status of the host, the environment and known or as yet unidentified pathogen/s [7, 8]. Indeed, another infective agent - a herpes-like virus - has also been associated with mortality episodes, although not systematically [8]. Besides $V$. aestuarianus and $V$. splendidus, another bacterial species not yet reported in France, $V$. tubiashii, has been found to be responsible for a serious disease in North American hatchery-reared Crassostrea virginica oysters [9] and C. gigas [10, 11].

Various extracellular proteases that play an important role in the pathogenesis of bacterial infections have been described in Vibrio isolated from seawater, fish and shellfish [12-16]. Proteases may be involved in tissue invasion and destruction, host defence evasion and its modulation [17]. Many proteases belong to the metalloprotease family [18]. Those produced by human pathogenic bacteria, including $V$. cholerae and $V$. vulnificus, have been studied extensively, evidencing a broad range of pathological actions [19]. Metalloproteases have been also described in some V. tubiashii, V. aestuarianus and V. splendidus strains pathogenic to Pacific oyster $C$. gigas [20-22]. It has been recently shown by mutagenesis that those produced by two strains related to $V$. tubiashii and $V$. splendidus are an essential determinant of lethality when extracellular products are injected into $C$. gigas oysters $[9,21,23,24]$.

In previous studies, $V$. splendidus and $V$. aestuarianus strains associated with mortality episodes of cultivated $C$. gigas oysters in France were isolated in (1) sentinel animals that had been kept in experimental cohabitation in an aquarium with presumed diseased animals collected from areas where mortality episodes were noted [25], or (2) in temporally and spatially limited mortality outbreaks $[3,4]$. The first aim of the present study was to increase the number of identified bacteria associated with mortality episodes, mainly in cultivated Pacific oysters but also in three other mollusc species cultivated in France. This was done during a four-year bacteriological survey, allowing us to evaluate the representativeness of $V$. splendidus and $V$. aestuarianus bacterial strains. The second aim of the present study was to screen several of the bacterial strains found to be more frequently associated with mollusc disease outbreaks, to evaluate both their pathogenicity in $C$. gigas spat by experimental infection and their ability to produce metalloprotease-like activity in culture supernatant fluids. Results from these investigations allowed us to correlate metalloprotease activity and virulence capacity.

\section{Materials and methods}

\section{Sampling and bacterial isolation}

Abnormal mortality in mollusc aquaculture is defined by European Directive 95/70/EC as a sudden mortality affecting approximately $15 \%$ of stocks and occurring over a short period between two inspections (within 15 days). In practice, the study of abnormal mortality in France is the subject of passive monitoring: mollusc mortality cases are reported by farmers to the competent authority and the French network of shellfish pathology, known as REPAMO, records and performs analyses on the animals. Mortality rate is estimated by counting a proportion of live and dead animals in three 
randomly chosen bags per oyster lease, three randomly chosen tanks in hatcheries-nurseries or in three different squares for clam and scallop beds..

Over four years of zoosanitary monitoring performed by the REPAMO network (2003, 2004, 2005 and 2007), 92 batches of animal samples were collected from abnormal mortality episodes affecting 4 cultivated mollusc species. Samples were mainly Pacific oysters C. gigas (80\% of samples), but also scallops Pecten maximus (3\%), clams Ruditapes philippinarum (5\%) and abalone Haliotis tuberculata (12\%). The affected animals mainly came from private farms, in 36 different locations along the Atlantic, English Channel or Mediterranean coasts of France; $47 \%$ of oyster samples came from two IFREMER experimental facilities. Animals presumed to be diseased were shipped at $4{ }^{\circ} \mathrm{C}$ by express courier ( $<24$ hours) to the IFREMER pathology laboratory. Bacterial isolations were only made from animals that were still alive on arrival. Generally, two apparently healthy animals and at least three diseased animals exhibiting a weakness in adductor muscle tonicity were examined and analysed by bacteriological methods. In order to prevent any risk of bacterial contaminations from diseased to apparently healthy animals, each group of animals was shipped in a different plastic bag. Depending on mollusc species and age of the animals, different tissues were sampled in sterile conditions for bacteriological analysis: haemolymph was taken for each oyster or abalone; a piece of adductor muscle, gill and mantle mixed together for each scallop; and a mixture of five mantles from individual clams. All these tissues were prepared using five individuals or five pools of animals from each batch, and in each case corresponded either to an all-adult or all-juvenile age class. Haemolymph was withdrawn into a syringe from the adductor muscle or pericardial cavity of oysters and from the pericardial cavity of abalones, using a 23-gauge needle. Tissues from scallop and clams were homogenized in 100 $\mu \mathrm{l}$ Sterile Artificial Sea Water diluent (SASW $2.3 \% \mathrm{NaCl}, 20 \mathrm{mM} \mathrm{KCl}, 5 \mathrm{mM} \mathrm{MgSO}$, $2 \mathrm{mM} \mathrm{CaCl}_{2}$ ) with a sterile pellet-pestle (Sigma) for 1 minute on average. For larvae and early spat stages (shell size smaller than $3 \mathrm{~cm}$ in length), several whole animals were taken and disrupted in SASW as a single pool of individuals for each batch sample.

Tissue samples diluted in SASW (10 to 1000x) were spread on Thiosulfate-Citrate-Bile SaltsSucrose (TCBS, Difco) agar in Petri dishes. After incubation of plates at $20^{\circ} \mathrm{C}$ for at least 4 days, each macroscopically different bacterial isolate found in abundance (more than $10^{4} \mathrm{CFU} / \mathrm{ml}$ ) was re-plated on nutrient Petri dishes to check for purity. Each isolate was identified by eight figures, the first two indicating the year of batch reception, the next three indicating the batch number and the last ones giving the sample tissue number followed by the colony type (T) number.

\section{Genotyping}

Bacterial isolates were cultured overnight at $20{ }^{\circ} \mathrm{C}$ in marine broth (Difco), and $65 \mu \mathrm{l}$ of bacterial suspension were deposited on FTA ${ }^{\circledR}$ paper matrix cards according to the manufacturer's instructions (Whatman) for nucleic acids extraction and storage. The 16S rRNA and gyrB genes were amplified using universal bacterial primer pairs SAdir (5'-AGAGTTTGATCATGGCTCAGA-3'), S17rev (5'-GTTACCTTGTTACGACTT-3') and Up1E GAAGTCATCATGACCGTTCTGCAYGCNGGNGGNAARTTYRA-3'), UP2R (5'AGCAGGGTACGGATGTGCGAGCCRTCNACRTCNGCRTCNGYCAT-3'), following methods described by Lambert et al. [26] and Yamamoto and Harayama [27], respectively. The amplicons with the expected size were purified using a Microcon PCR filter kit (Millipore). Purified PCR products were mixed (final volume $10 \mu \mathrm{l}$ ) with $0.4 \mu \mathrm{I} \mathrm{ABI}$ Prism Big Dye Terminator ready reaction mix (Applied Biosystems), $0.75 \mu \mathrm{M}$ forward primer using SAdir for the 16S rRNA sequencing reaction and Up1S 5'-GAAGTCATCATGACCGTTCTGCA-3' for gyrB sequencing. Cycle sequencing reactions were performed using a Gene Amp PCR System 2700 (Applied Biosystems) following manufacturer's instructions. Separation of the DNA fragments was carried out in an $A B I$ PRISM 3100 Genetic Analyzer (Applied Biosystems).

Sequences were then compared against those of the type strains of validly published species using Eztaxon [28]. Sequences from bacterial isolates and closed type strains were aligned with BioEdit [29] and phylogenetic trees were built using Mega4 [30] and the Neighbour-Joining method with the Kimura two-parameter model. Reliability of topologies was assessed by the bootstrap method [31] with 1000 replicates. 


\section{Metalloprotease-like activity in culture supernatant fluids}

Proteolytic activity in culture supernatant fluids (CSF) was determined using azocasein (Sigma Chemical Co., St. Louis, MO) as a substrate, according to the method of Teo et al, [32] with slight modifications. Briefly, pure bacterial culture was incubated in Marine Broth (Difco) at $20^{\circ} \mathrm{C}$ for $48 \mathrm{~h}$ on a shaker to yield stationary phase. Bacterial concentrations ranged between $5 \times 10^{7}$ and $2 \times 10^{8}$ $\mathrm{CFU} / \mathrm{ml}$ according to bacterial strains, as evaluated by the plate-counting method using appropriate dilution. Culture supernatant fluids were harvested by centrifugation $\left(3200 \times \mathrm{g}, 20^{\circ} \mathrm{C}, 10 \mathrm{~min}\right)$, and $250 \mu \mathrm{l} \mathrm{CSF}$ were added to $250 \mu \mathrm{l}$ azocasein $(5 \mathrm{mg} / \mathrm{ml}$ ) prepared in $50 \mathrm{mM}$ Tris- $\mathrm{HCl}$ buffer (pH 8.0). The mixture was incubated at $37^{\circ} \mathrm{C}$ for $2 \mathrm{~h}$ and the reaction stopped by adding $500 \mu \mathrm{l}$ cold $10 \%$ trichloroacetic acid. After centrifugation at $12000 \mathrm{~g}$ and $4{ }^{\circ} \mathrm{C}$ for $5 \mathrm{~min}, 500 \mu \mathrm{l}$ of the supernatant were mixed with $500 \mu \mathrm{l} 1 \mathrm{M} \mathrm{NaOH}$ and the absorbance measured at $440 \mathrm{~nm}$. One unit of protease activity was defined as the amount of enzyme that caused an increase of 0.01 absorbance unit after $2 \mathrm{~h}$ incubation at $37^{\circ} \mathrm{C}$ [32].

To confirm metalloprotease-like activity in culture supernatants, CSF were assayed with azocasein under the conditions described above, adding a CSF preincubation step at $20{ }^{\circ} \mathrm{C}$ for $30 \mathrm{~min}$ in the presence of metalloprotease inhibitors $8 \mathrm{mM}$ 10-phenanthroline or $40 \mathrm{mM}$ EGTA [32].

\section{Experimental infections}

Bacteria were grown at $20{ }^{\circ} \mathrm{C}$ for $20 \mathrm{~h}$ in marine broth under constant shaking. The bacterial culture concentrations were evaluated spectrometrically at an optical density (OD) of $600 \mathrm{~nm}$. Cells were centrifuged at $3200 \mathrm{~g}$ for $10 \mathrm{~min}$, the supernatant discarded and the resulting pellet resuspended in SASW to obtain an OD of 1 . Ten- to twelve-month-old oyster spat were anaesthetised for 1 to 2 hours at $20{ }^{\circ} \mathrm{C}$ in a solution of magnesium chloride $\left(28 \mathrm{~g} / \mathrm{L} \mathrm{MgCl}_{2}\right)$ supplemented with phytoplankton (Isochrysis galbata and Chaetoceros calcitrans) under aeration. Subsequently, $100 \mu \mathrm{L}$ of bacterial suspension were injected into the adductor muscle. A group of oysters were injected with SASW to serve as negative controls. Virulent $V$. splendidus LGP32 strain [5] and $V$. aestuarianus 02/041 strain [3] isolated in experimental cohabitation trials and from the IFREMER experimental hatchery at Argenton (Brittany, France), respectively, were used as positive controls. After injection, oysters were transferred to tanks (20 to 30 oysters in $2 \mathrm{~L}$ ) filled with $1 \mu \mathrm{m}$-filtered seawater at $3.1 \%$ of salinity and maintained under static conditions at $20^{\circ} \mathrm{C}$ with aeration. Mortality was monitored daily and any newly dead oysters were removed from the tanks over a seven-day period.

\section{Results}

\section{Phylogenetic analysis}

A total of 183 bacterial isolates were obtained from four cultivated mollusc species collected during mortality episodes $(n=92)$. All isolates were found dominant by the plate culture method at $1000 x$ dilution. They were mainly isolated from diseased animals, in contrast to results with apparently healthy animals originating from a same batch, where no cultivable bacteria were observed at the same dilution. Small-subunit ribosomal RNA genes of these isolates were partially sequenced (around $700 \mathrm{bp}$ ). Sequence comparisons between isolates of a single tissue sample revealed that identical nucleotide sequences could be obtained, revealing the existence of 147 tissue samplespecific strains. Phylogenetic analysis (Fig. 1) of 120 strains with high quality sequences revealed that most of these strains clustered with reference strains of bacterial species related to polyphyletic groups of Vibrio splendidus (38 strains) or $V$. harveyi (32), and monophyletic groups of V. aestuarianus (18), Shewanella colwelliana (9), V. chagasii (5), V. fortis (4) and V. tapetis (3). To define the taxonomic affiliation of $V$. splendidus-related strains, a phylogenetic analysis was performed on the gyrB gene (Fig. 2) using 15 representative strains obtained in Fig. 1. Twelve of 
these strains were affiliated to the $V$. splendidus type strain, one (05/013 2T1) to the $V$. crassostreae type strain and one (04/112 1T1 strain) was found in the cluster composed of $V$. lentus, $V$. tasmaniensis, $V$. kanaloae and $V$. pomeroyi type strains. An additional strain (03/126 1T2) was found not to be affiliated to any Vibrio species yet described.

\section{Strain distribution}

A total of 115 strains were isolated from $C$. gigas collected during 73 mortality episodes between 2003 and 2007, mainly during the hot season between May and October (Table 1). Among these, 63 strains (isolated from 39 mortality episodes) originated from 21 private farms in different localities and 52 strains (isolated from 34 mortality episodes) from experimental facilities of IFREMER in Bouin (Vendée) and La Tremblade (Charente Maritime) (Fig. 3). The strains encountered most frequently belonged to the $V$. splendidus group, $V$. harveyi group or $V$. aestuarianus: representing 32/115 (28 \%), 27/115 (23\%) and 25/115 (22\%) of the total strains, respectively. Analysis of the distribution of the strains obtained from private farms along French coasts, according to the type of production structure, revealed that $V$. splendidus was detected in both tidal areas and indoor facilities at $33 \%$ and $27 \%$, respectively. In contrast, $V$. aestuarianus was mainly found in open sea intertidal areas (11 over 12 strains). A discrepancy between these two Vibrio species was also noticed according to oyster age. In contrast to $V$. splendidus, which was found in oysters of all ages, $V$. aestuarianus strains were only found in juvenile or adult animals. The same tendency was seen in the IFREMER experimental facilities (11 over 13 strains). Study of the geographical distribution of $V$. splendidus-related bacterial strains revealed that these strains were present all along the Atlantic, English Channel and Mediterranean coasts of France (data not shown). Surprisingly, $V$. aestuarianus was present along the whole Atlantic coast and English Channel but was not detected in oysters cultivated on the Mediterranean. Among the other bacterial species most frequently detected in C. gigas, $11 \mathrm{~V}$. harveyi-related and $8 \mathrm{~S}$. colwelliana strains were isolated from oysters sampled on private farms, mainly from indoor facilities (hatcheries and nurseries); $33 \%$ and $20 \%$ detection frequencies were shown for these species, respectively, mainly found to be associated with mortality events affecting earlier life stages (24\% and $17 \%$ respectively). Vibrio harveyi-related strains were also frequently detected in young animals bred in the IFREMER experimental facilities (50\%), in contrast to $S$. colwelliana, for which only one strain was isolated out of 32. Interestingly, only two $V$. harveyi strains were detected between 2003 and 2005, whereas 25 new ones were isolated in 2007. Reports of $V$. harveyi strains were confined to three open sea rearing sites on the Mediterranean coast and Arcachon Bay (6 strains), two private hatcheries or nurseries (5 strains) and the IFREMER experimental facilities (16 strains). Other bacterial species detected less frequently were $V$. chagasii, $V$. fortis and $V$. tapetis.

Another 32 bacterial strains were isolated from other mollusc species of economic interest in the context of 19 mortality events that occurred between 2003 and 2007 in Brittany, Normandy and Vendée. The most frequently detected bacterial species were $V$. splendidus and $S$. colwelliana (Table 2) found in scallops Pecten maximus, clams Ruditapes philippinarum and abalones Haliotis tuberculata, representing $62 \%$ of total strains. Furthermore, $H$. tuberculata was frequently found to be infected with $V$. harveyi strains (6 out of 14 ).

Considering all the tissue samples analysed, some cases of co-infection by multiple bacterial species were noted. In particular, the presence of both $V$. aestuarianus and $V$. splendidus strains in the same sample was found 9 times among the 92 batches of animals analysed.

\section{Strain screening for virulence in C. gigas and metalloprotease activity}

Several strains were selected from the more representative phylogenetic clades found in this study, corresponding to bacteria isolated during mortality events in four cultivated bivalve molluscs (Table 3): 14 strains belonged to the $V$. splendidus group, 9 to the $V$. harveyi group, $10 \mathrm{~V}$. aestuarianus strains and $5 \mathrm{~S}$. colwelliana strains. Vibrio splendidus-related strains were mainly those typed by the gyrB phylogenetic approach, whereas strains related to other well represented phylogenetic clades were selected arbitrarily from our bacteria collection. All tested $V$. aestuarianus 
and $V$. harveyi strains were found virulent by experimental injection of oysters with live bacteria whereas S. colwelliana strains were mainly avirulent, except for one strain (07/082 T2). Virulence was variable among $V$. splendidus-related strains. In particular, 4 field isolates plus one $V$. tasmaniensis type strain were found to be non-pathogenic. The peak of mortality induced by virulent strains was generally seen between the first and second day of infection challenge for $V$. splendidus-related strains, between day 2 and day 3 for $V$. aestuarianus strains and in the first 20 hours post challenge for $V$. harveyi strains.

Metalloprotease-like activities of culture supernatants and virulence status were compared for each of the tested strains, whatever their species, and a contingency table was built (table 4): $76 \%$ of strains displayed metalloprotease-like activities or virulence capacities, whereas $24 \%$ were found negative for both tests and a correlation was revealed. Concordant results were obtained for 32 strains out of 38 (84\%), with 26 and 6 strains found positive and negative for the two tests, respectively. Divergent results between the two tests were obtained for $V$. splendidus-related strains (3 strains), V. harveyi-related strains (2 strains) and S. colwelliana (1 strain), but not for $V$. aestuarianus strains. Finally, $90 \%$ of metalloprotease positive strains were found to be virulent.

\section{Synergistic virulence effect of Vibrio co-infection}

Following the evidence for cases of natural co-infection by $V$. aestuarianus and $V$. splendidus, well characterized LGP32 and 02/041 strains were injected together to study their pathogenicity and compare it with injection of single strain bacterial injection at the same dose (Fig. 4). The use of a mixture of LGP32 and 02/041 strains at a dose of $510^{7}$ CFU oyster ${ }^{-1}$ for each strain gave a mortality rate of $88.9 \%$, which was higher than the mortality rate obtained when bacteria were injected alone at the same dose i.e. $10^{8} \mathrm{CFU}$ oyster $^{-1}$ (60 and $53.3 \%$, respectively). Furthermore, lowering the injected dose of the LGP32 and 02/041 mixture by a factor of 10 or 100 resulted in lower but significant cumulative mortalities, with rates of 84.7 and $34.4 \%$, respectively, whereas a $1 / 100$ dilution factor removed the pathogenicity of these strains when they were used individually (data not shown). Furthermore, whatever the bacteria used in experimental challenges, we verified with the plate counting method that haemolymph samples from some freshly dead oysters harboured dominant bacteria belonging to the same species as those injected, fulfilling one of the Koch's postulates (data not shown).

\section{Discussion}

Previous geographically and temporally limited bacteriological studies performed during summer mortality phenomena in Pacific C. gigas oysters reared in France have shown that two Vibrio species, $V$. aestuarianus and $V$. splendidus, are frequently, but not systematically, associated with summer mortality phenomenon with several strains demonstrated to be virulent for this oyster species in experimental infections $[3,25]$. In the present study we performed a large-scale epidemiological survey to identify the bacteria abundant in four mollusc species (mainly Pacific oyster) cultivated in France during 92 mortality episodes between 2003 and 2007 and evaluate experimentally their virulence. Throughout this survey, histological analyses were also performed on 30 animals for each sample batch received, but no other important pathogenic agent was detected (data not shown).

Strong seasonality was observed in mortality episodes, as 68 out of the 73 in C. gigas grown in open sea sites occurred between May and September, with an onset in June $(39 / 68=57 \%)$ that coincided with the period of summer mortality phenomena. Incidence of $V$. aestuarianus and $V$. splendidus in oyster mortality outbreaks was confirmed, since a high frequency of detection (22\% and $28 \%$, respectively) was noted among the 115 identified strains. As observed in previous studies [33], isolated $V$. splendidus strains belong to a genetically complex polyphyletic group constituted by at least eight species [34]. Using gyrB as one of the more polymorphic housekeeping genes for phylogenetic analysis of this group, the majority of $V$. splendidus-related strains isolated (12 out of 15 ) were affiliated to the $V$. splendidus type strain. In contrast, isolated $V$. aestuarianus strains seemed to be genetically similar, with less than $1 \%$ nucleotide variation in 
their 16S rDNA gene. Both $V$. splendidus-related and, especially, $V$. aestuarianus species were more frequently detected in oysters reared in the open sea than in indoor facilities of private farms (33\% and $23 \%$ compared with $27 \%$ and less than $5 \%$, respectively) suggesting that coastal waters harbour these two organisms naturally. Indeed, $V$. splendidus-related strains were shown to be the most abundant planktonic species among the Vibrionaceae [35]. The fact that Vibrio aestuarianus was more frequently $(25 \%)$ detected in oysters reared in IFREMER indoor experimental facilities suggests that infectiosity of these organisms may be favoured by zootechnical practices, such as the use of low and frequently thermo-regulated rearing water flow. However, we cannot exclude the possibility that these data arose from an improved reactivity in detection and bacteriological sampling during mortality episodes, due to the close proximity of oysters to the IFREMER laboratory. The observation of symptomatology (weakness of the adductor muscle) may also have been easier than in field-reared oysters.

Other more frequently detected bacteria species associated with $C$. gigas mortality events encompassed $V$. harveyi and $S$. colwelliana. Similar to the $V$. splendidus group, $V$. harveyi has been shown by a multilocus sequence typing approach to be constituted of at least 7 species displaying a very high degree of both genetic and phenotypic similarity [36]. It seems relevant to note that in our study the number of $V$. harveyi-related strains associated with $C$. gigas mortality events rapidly increased in 2007, to 25 strains, whereas only two were isolated between 2003 and 2005. Further molecular typing studies are needed to assess the degree of similarity between these geographically distant isolates. In contrast, Shewanella spp. has never, to our knowledge, been associated with disease outbreaks in cultivated bivalve molluscs. In the present study, only one strain out of 5 was found to be moderately pathogenic for $C$. gigas oysters in experimental infections. This bacteria is reported to be a commensal in O. edulis [37] and C. virginica [38] oysters. Because $S$. colwelliana bacterial colonies isolated in this study display a similar macroscopic appearance to $V$. splendidus, and because cases of co-infection of samples by $S$. colwelliana and $V$. splendidus-related strains were frequently encountered (data not shown), we can hypothesize that we overestimated sample bacterial load due to S. colwelliana by erroneously considering that this bacterium could be dominant.

The association of microorganisms with animal tissue can be commensal, mutualistic, pathogenic or coincidental, due to the filter feeding behaviour of molluscs. As a consequence, many bacterial species and genera (mainly Vibrio) have been described as components of the bacterial flora naturally harboured by molluscs [39-43]. Nevertheless, they may act as opportunistic pathogens under adverse circumstances or in immuno-compromised animals. In our experience, the cultivable bacterial flora of healthy $C$. gigas oysters ranges from $10^{2}$ to $10^{4} \mathrm{CFU} / \mathrm{mg}$ tissue according to the origin of the oysters and the season, with a tendency towards higher bacterial load in oyster tissues when seawater temperature is higher $\left(>19^{\circ} \mathrm{C}\right)$. In the present study, we considered that all bacterial isolates found dominant by the plate counting method were potentially pathogenic and not of environmental origin because they were isolated in a context of mortalities and found to be present at abnormal concentrations ( $>10^{4} \mathrm{CFU} / \mathrm{mg}$ ), mainly in tissue samples originating from diseased animals. Nevertheless, we cannot exclude the possibility that less abundant non-dominant bacteria could be also pathogenic and could be the primary etiological agent of disease. These bacteria may be also counter-selected by culture conditions or be uncultivable on the synthetic medium used.

Using standardized experimental challenges on healthy oysters, as described by Gay et al. [25] and Labreuche et al. [44, 45], we evaluated the potential virulence status of some strains belonging to the more frequently occurring species in our collection. Most $V$. splendidus but all $V$. harveyirelated and $V$. aestuarianus strains tested were found virulent. Using two extensively studied pathogenic strains, LGP32 [25] and 01/042 [3], described by the same authors as one of the most virulent strains for $C$. gigas oyster and related to $V$. splendidus and $V$. aestuarianus, respectively, a synergistic effect was observed between these two strains when they were injected simultaneously. Such a phenomenon had already been observed in $C$. gigas oysters experimentally infected with two genetically close strains related to $V$. splendidus [5]. These results suggest that some not yet identified strain-specific virulence mechanisms are involved in pathogenicity expression. Because natural cases of co-infection by these two species-specific 
pathogens have been observed in our study, such synergistic virulence effects between two different Vibrio species would be expected to occur in some natural C. gigas disease outbreaks.

Although $V$. splendidus strains have already been found to be associated with mortality events in P. maximus [26, 46] and carpet shell clam Ruditapes decussatus [47] this is the first time, to our knowledge, that $V$. splendidus has been found to be associated with the mortality of clam Ruditapes philippinarum or abalone Haliotis tuberculata. Even though further studies are needed to demonstrate their role in disease outbreaks of these other mollusc species, it is noticeable that several $V$. splendidus strains isolated from $R$. philippinarum were found to be virulent for $C$. gigas in experimental infection, suggesting that a common agent may infect different mollusc species. Similarly, considering $V$. harveyi, a well known pathogen of cultivated Haliotis tuberculata in France $[48,49]$, two strains isolated in this study exhibited a pathogenic effect on $C$. gigas when evaluated by experimental infection. In contrast to other $V$. splendidus or $V$. harveyi strains studied, which seemed to be ubiquitous, those identified as $V$. aestuarianus appear to only induce disease in $C$. gigas.

Finally, a high level of concordant results between azocaseinase activities and virulence of strains were obtained in this study. Azocaseinase activity was assumed to be due to a metalloproteaselike enzyme following the results of zinc-dependant chelators, such as phenanthrolein or EGTA inhibitory treatments (data not shown), with up to $90 \%$ inhibition for most strains and partial inhibition for a limited number of strains. Despite this correlation, metalloprotease appeared not to be the only virulence determinant of virulent strains, because 3 strains were found to be devoid of this enzyme, though they were in a minority compared with the 29 tested-virulent strains. Conversely, 3 among 9 avirulent strains exhibited metalloprotease activity, suggesting that these bacteria were unable to produce this enzyme in in vivo.. In any case, the role of metalloprotease in pathogenesis of vibriosis in different host species has been explored by several in vitro approaches. Several host substrates and culture conditions for efficient metalloprotease production have been identified that could be involved in invasion process [19, 32, 50-54]. In contrast, few approaches have been conducted in vivo that aim to demonstrate the role of metalloproteases in virulence induced by Vibrio infection. This could be due to the lack of mutant strains, lack of tools to quantify metalloprotease production or its expression by pathogens during infection, or the absence of appropriate infection models. The small number of virulence studies that have been realized using mutants deficient in metalloprotease gave mitigated results and conclusions. Infecting fish with wild or metalloprotease-mutated pathogenic strains of $V$. anguillarum, Milton et al. [55] and Denkin and Nelson [51] noticed contrasted virulence profiles according to strains, infection route and infection model. For example, the NB10 metalloprotease-deficient mutant was found to be completely avirulent when injected intraperitoneally or by anal intubation into Atlantic salmon [51], whereas the same mutant exhibited attenuated virulence when administered to rainbow trout by intraperitoneal injection or immersion challenge [55]. Furthermore, metalloprotease mutant M99 derived from another virulent Vibrio anguillarum strain was found to be as virulent as the wild strain when injected intraperitoneally and to display attenuated virulence when administered by anal intubation [51]. In Vibrio sp. strains pathogenic to C. gigas oysters, high homology between amino acid sequences deduced from metalloprotease genes has been noticed, suggesting a similar role in pathogenesis. Those from V. splendidus LGP32 and Vibrio tubiashii RE22 strains (named vsm and Vtpa with GenBank accession numbers ACD87449 and CAV18407 respectively) displayed $75 \%$ identity and $88 \%$ similarity. Similarly, whole genome sequencing comparisons between LGP32 and two other geographically distant virulent strains related to $V$. splendidus (Med222 and 12B01), showed that genes encoding metalloprotease shared more than $98 \%$ identity and that vsm was localised on chromosome 1 in a region (position 1673 2211365498 ) devoid of genome plasticity $[21,56]$. The predicted product of vsm gene product exhibits $67 \%$ identity and $81 \%$ similarity with $V$. aestuarianus strain 01/032 (AAU04777) or with $V$. anguillarum strain NB10 (AAA27517). The deletion of vsm and Vtpa genes from LGP32 and RE25 strains was shown to decrease the toxicity of extracellular products towards $C$. gigas spat and larvae $[21,24]$. Furthermore, the metalloprotease activity and toxicity of vsm mutant were restored by ectopic complementation, suggesting that metalloprotease is important in its pathogenicity to oyster. Nevertheless, the fact that the vsm mutant displays an equal virulence to the parental strain 
when injected intramuscularly to oyster [21] suggests that this metalloprotease may interact with other virulence factors that still need to be identified and/or that the experimental infection model used here, via an invasive route, is inappropriate.

To our knowledge, this is the first time that a correlation has been reported between $C$. gigas pathogenic bacterial strains related to $V$. aestuarianus, or polyphyletic groups of $V$. splendidus and $V$. harveyi, and the ability of these bacteria to produce metalloprotease in culture supernatants following large-scale strain screening from an epidemiological study. Because $V$. harveyi strains were recently isolated from C. gigas oyster mortality events occurring in France (mainly in 2007), further epidemiological studies and molecular typing methods are needed to gain an idea of whether a new $C$. gigas pathogen has emerged and to identify strains related to this complex polyphyletic group to the species level. Bacterial metalloprotease activities appear in this study as a common feature of pathogenic bacteria strains associated with mortality events of $C$. gigas reared in France, suggesting that this phenotypic test could be useful for the evaluation of virulence in bacterial strains associated with such mortality episodes. Indeed, experimental infection trials to evaluate virulence potential of bacterial strains are time consuming, as they require at least five consecutive working days, as well as dedicated experimental facilities, including a system for treating of seawater effluents. In contrast, measurement of metalloprotease activities requires less time (estimated at a total of one day of work for the treatment of approximately thirty bacterial strains). Few studies had been previously conducted in vivo to demonstrate the involvement of metalloproteases in virulence during Vibrio infection, compared with the number of in vitro studies. There is, therefore, a huge need to develop molecular and biochemical tools to study the encoding gene(s) at both the expression and translation level, and to identify host and environmental factors modulating the production of metalloprotease by both pathogenic and presumed commensal bacterial strains. For this purpose, the use of a non-invasive experimental model for infection of oysters with pathogenic Vibrio will be very useful and will allow future studying of the interactions between metalloprotease and other virulence factors that still need to be identified.

\section{Acknowledgments}

We thank Helen McCombie for her help with English editing.

\section{References}

1. Fleury PG, Goyard E, Mazurie J, Claude S, Bouget JF, Langlade A, Le Coguic Y (2001) The assessing of Pacific oyster (Crassostrea gigas) rearing performances by the IFREMER/REMORA network: method and first results (1993-98) in Brittany (France). Hydrobiologia 465: 195-208

2. Saulnier D, De Decker S, Haffner P (2009) Real-time PCR assay for rapid detection and quantification of Vibrio aestuarianus in oyster and seawater: A useful tool for epidemiologic studies. J Microbiol Methods 77: 191-197

3. Garnier M, Labreuche Y, Garcia C, Robert M, Nicolas JL (2007) Evidence for the involvement of pathogenic bacteria in summer mortalities of the Pacific oyster Crassostrea gigas. Microb Ecol 53: 187-196

4. Le Roux F, Gay M, Lambert C, Waechter M, Poubalanne S, Chollet B, Nicolas JL, Berthe F (2002) Comparative analysis of Vibrio splendidus-related strains isolated during Crassostrea gigas mortality events. Aquat Living Resour 15: 251-258

5. Gay M, Renault T, Pons AM, Le Roux F (2004) Two Vibrio splendidus related strains collaborate to kill Crassostrea gigas: taxonomy and host alterations. Dis Aquat Organ 62: 65-74

6. Soletchnik P, Ropert M, Mazurie J, Fleury PG, Le Coz F (2007) Relationships between oyster mortality patterns and environmental data from monitoring databases along the coasts of France. Aquaculture 271: 384-400 
7. Goulletquer P, Soletchnik P, Le Moine O, Razet D, Geairon P, Faury N (1998) Summer mortality of the Pacific cupped oyster Crassostrea gigas in the Bay of Marennes-Oleron (France). Counc Meet of the Int Counc for the Exploration of the Sea, Cascais (Portugal), 16-19 Sep 1998: 20p.

8. Samain JF, McCombie H (2008) Summer mortality of Pacific oyster Crassostrea gigas. The Morest Project. Editions Quae. 379p.

9. Tubiash HS, Chanley PE, Leifson E (1965) Bacillary Necrosis, a disease of larval and juvenile bivalve mollusks. J Bacteriol 90: 1036-1044

10. Estes R, Friedman C, Elston R, Herwig R (2004) Pathogenicity testing of shellfish hatchery bacterial isolates on Pacific oyster Crassostrea gigas larvae. Dis Aquat Organ 58: 223-230

11. Elston RA, Hasegawa H, Humphrey KL, Polyak IK (2008) Re-emergence of Vibrio tubiashii in bivalve shellfish aquaculture: severity, environmental drivers, geographic extent and management. Dis Aquat Organ 82: 119-134

12. Inamura H, Nakai T, Muroga K (1985) An extracellular protease produced by Vibrio anguillarum. Bulletin of the Japanese Society of Scientific Fisheries 51: 1915-1920

13. Lee KK, Liu PC, Chuang WH (2002) Pathogenesis of gastroenteritis caused by Vibrio carchariae in cultured marine fish. Mar Biotechnol 4: 267-277

14. Lee KK, Chen YL, Liu PC (1999) Hemostasis of Tiger prawn Penaeus monodon affected by Vibrio harveyi, extracellular products, and a toxic cysteine protease. Blood Cells Mol Dis 25: 180192

15. Lee KK, Yu SR, Liu PC (1997) Alkaline serine protease is an exotoxin of Vibrio alginolyticus in Kuruma prawn, Penaeus japonicus. Curr Microbiol 34: 110-117

16. Nottage AS, Birkbeck TH (1987) Production of proteinase during experimental infection of Ostrea edulis L. larvae with Vibrio alginolyticus NCMB 1339 and the antigenic relationship between proteinases produced by marine vibrios pathogenic for fish and shellfish. J Fish Dis 10: 265-273

17. Travis J, Potempa J, Maeda H (1995) Are bacterial proteinases pathogenic factors? Trends Microbiol 3: 405-407

18. Hase CC, Finkelstein RA (1993) Bacterial extracellular zinc-containing metalloproteases. Microbiol Rev 57: 823-837

19. Miyoshi SI, Shinoda S (2000) Microbial metalloproteases and pathogenesis. Microbs Infect 2: $91-98$

20. Labreuche Y, Soudant P, Goncalves M, Lambert C, Nicolas JL (2006) Effects of extracellular products from the pathogenic Vibrio aestuarianus strain 01/32 on lethality and cellular immune responses of the oyster Crassostrea gigas. Dev Comp Immunol 30: 367-379

21. Le Roux F, Binesse J, Saulnier D, Mazel D (2007) Construction of a Vibrio splendidus mutant lacking the metalloprotease gene vsm by use of a novel counterselectable suicide vector. Appl Environ Microbiol 73: 777-784

22. Delston R, Kothary M, Shangraw K, Tall B (2003) Isolation and characterization of a zinccontaining metalloprotease expressed by Vibrio tubiashii. Can J Microbiol 49: 525-529

23. Binesse J, Delsert C, Saulnier D, Champomier-Verges MC, Zagorec M, Munier-Lehmann $\mathrm{H}$, Mazel D, Le Roux F (2008) The metalloprotease Vsm is the main toxic factor for Vibrio splendidus extracellular products. Appl Environ Microbiol 74: 7108-7117

24. Hasegawa H, Lind EJ, Boin MA, Hase CC (2008) The extracellular metalloprotease of Vibrio tubiashii is a major virulence factor for Pacific oyster (Crassostrea gigas) larvae. Appl Environ Microbiol 74: 4101-4110

25. Gay M, Berthe FC, Le Roux F (2004) Screening of Vibrio isolates to develop an experimental infection model in the Pacific oyster Crassostrea gigas. Dis Aquat Organ 59: 49-56

26. Lambert C, Nicolas JL (1998) Specific inhibition of chemiluminescent activity by pathogenic vibrios in hemocytes of two marine bivalves: Pecten maximus and Crassostrea gigas. J Invertebr Pathol 71: 53-63

27. Yamamoto S, Harayama S (1995) PCR amplification and direct sequencing of gyrB genes with universal primers and their application to the detection and taxonomic analysis of Pseudomonas putida strains Appl Environ Microbiol 61: 1104-1109

28. Chun J, Lee JH, Jung Y, Kim M, Kim S, Kim BK, Lim YW (2007) EzTaxon: a web-based tool for the identification of prokaryotes based on 16S ribosomal RNA gene sequences. Int J Syst Evol Microbiol 57: 2259-2261 
29. Hall T (1999) BioitEdit: a user-friendly biological sequence alignment editor and analysis program for Windows 95/98/NT. Nucl Acids Symp Ser 41: 95-98

30. Tamura K, Dudley J, Nei M, Kumar S (2007) MEGA4: Molecular Evolutionary Genetics Analysis (MEGA) Software Version 4.0. Mol Biol Evol 24: 1596-1599

31. Felsenstein J (1985) Confidence limits on phylogenies: an approach using the bootstrap. Evolution 39: 783-791

32. Teo JWP, Zhang LH, Poh CL (2003) Cloning and characterization of a metalloprotease from Vibrio harveyi strain AP6. Gene 303: 147

33. Le Roux F, Gay M, Lambert C, Nicolas JL, Gouy M, Berthe F (2004) Phylogenetic study and identification of Vibrio splendidus-related strains based on gyrB gene sequences. Dis Aquat Organ 58: 143-150

34. Faury N, Saulnier D, Thompson FL, Gay M, Swings J, Le Roux F (2004) Vibrio crassostreae sp. nov., isolated from the haemolymph of oysters (Crassostrea gigas). Int J Syst Evol Microbiol 54: 2137-2140

35. Thompson JR, Pacocha S, Pharino C, Klepac-Ceraj V, Hunt DE, Benoit J, SarmaRupavtarm R, Distel DL, Polz MF (2005) Genotypic diversity within a natural coastal bacterioplankton population. Science 307: 1311-1313

36. Sawabe T, Kita-Tsukamoto K, Thompson FL (2007) Inferring the evolutionary history of vibrios by means of multilocus sequence analysis. J Bacteriol 189: 7932-7936

37. Guisande JA, Montes M, Farto R, Armada SP, Perez MJ, Nieto TP (2004) A set of tests for the phenotypic identification of culturable bacteria associated with Galician bivalve mollusc production. J Shellfish R 3: 599-609

38. Weiner RM, Segall AM, Colwell RR (1985) Characterization of a marine bacterium associated with Crassostrea virginica (the Eastern oyster). Appl Environ Microbiol 49: 83-90

39. Colwell RR, Liston J (1960) Microbiology of shellfish. Bacteriological study of the natural flora of Pacific oysters (Crassostrea gigas). Appl Microbiol 8: 104-109

40. Macián M, Garay E, González-Candelas F, Pujalte M, Aznar R (2000) Ribotyping of Vibrio populations associated with cultured oysters (Ostrea edulis). Syst Appl Microbiol 23: 409-417

41. Olafsen JA, Mikkelsen HV, Giæver HM, Høvik Hansen G (1993) Indigenous bacteria in hemolymph and tissues of marine bivalves at low temperatures. Appl Environ Microbiol 59: 18481854

42. Ortigosa M, Garay E, Pujalte MJ (1994) Numerical taxonomy of Vibrionaceae isolated from oysters and seawater along an annual cycle. Syst Appl Microbiol 17: 216-225

43. Pujalte MJ, Ortigosa M, Macián MC, Garay E (1999) Aerobic and facultative anaerobic heterotrophic bacteria associated to Mediterranean oysters and seawater. Int Microbiol 2: 259-266

44. Labreuche Y (2006) Caractérisation de la virulence d'une souche de Vibrio aestuarianus, pathogène de l'huître creuse Crassostrea gigas. Université de Bretagne Occidentale, Brest, France, PhD, 277p.

45. Labreuche Y, Lambert C, Soudant P, Boulo V, Huvet A, Nicolas JL (2006) Cellular and molecular hemocyte responses of the Pacific oyster, Crassostrea gigas, following bacterial infection with Vibrio aestuarianus strain 01/32. Microbs Infect 8: 2715-2724

46. Nicolas JL, Corre S, Gauthier G, Robert R, Ansquer D (1996) Bacterial problems associated with scallop Pecten maximus larval culture. Dis Aquat Organ 27: 67-76

47. Gomez-Leon J, Villamil L, Lemos ML, Novoa B, Figueras A (2005) Isolation of Vibrio alginolyticus and Vibrio splendidus from aquacultured carpet shell clam (Ruditapes decussatus) larvae associated with mass mortalities. Appl Environ Microbiol 71: 98-104

48. Travers MA, Le Goïc N, Huchette S, Koken M, Paillard C (2008) Summer immune depression associated with increased susceptibility of the European abalone, Haliotis tuberculata to Vibrio harveyi infection. Fish Shellfish Immunol 25: 800-808

49. Nicolas JL, Basuyaux O, Mazurié J, Thébault A (2002) Vibrio carchariae, a pathogen of the abalone Haliotis tuberculata. Dis Aquat Organ 50: 35-43

50. Chang AK, Kim HY, Park JE, Acharya P, Park IS, Yoon SM, You HJ, Hahm KS, Park JK, Lee JS (2005) Vibrio vulnificus secretes a broad-specificity metalloprotease capable of interfering with blood homeostasis through prothrombin activation and fibrinolysis. J Bacteriol 187: 6909-6916 51. Denkin SM, Nelson DR (2004) Regulation of Vibrio anguillarum empA metalloprotease expression and its role in virulence. Appl Environ Microbiol 70: 4193-4204 
52. Takahashi KG, Nakamura A, Mori K (2000) Inhibitory effects of ovoglobulins on bacillary necrosis in larvae of the Pacific oyster, Crassostrea gigas. J Invertebr Pathol 75: 212-217

53. Watanabe H, Miyoshi SI, Kawase T, Tomochika KI, Shinoda S (2004) High growing ability of Vibrio vulnificus biotype 1 is essential for production of a toxic metalloprotease causing systemic diseases in humans. Microb Pathog 36: 117-123

54. Kim C-M, Kang S-M, Jeon H-J, Shin S-H (2007) Production of Vibrio vulnificus metalloprotease $\mathrm{VvpE}$ begins during the early growth phase: Usefulness of gelatin-zymography. $\mathrm{J}$ Microbiol Methods 70: 96-102

55. Milton DL, Norqvist A, Wolf-Watz H (1992) Cloning of a metalloprotease gene involved in the virulence mechanism of Vibrio anguillarum. J Bacteriol 174: 7235-7244

56. Le Roux F, Mohamed Z, Chakroun N, Binesse J, Saulnier D, Bouchier C, Zidane N, Ma L, Rusniok C, Lajus A, Buchrieser C, Médigue C, Polz MF, Mazel D (2009) Genome sequence of Vibrio splendidus: an abundant planctonic marine species with a large genotypic diversity. Environmental Microbiology 11: 1959-1970 


\section{Table 1}

Number of bacterial strains isolated from C. gigas during 73 mortality episodes between 2004 and 2007 and distribution according to production type (private farms or experimental facilities), rearing practices (open sea tidal areas or indoor facilities), age of animals (larvae and young spat of less 3 $\mathrm{cm}$ of size were treated in pools for bacteriological analysis, juveniles of more than $3 \mathrm{~cm}$ of size and adults were treated individually using haemolymph, see Material and Methods), season (the cold season is between October and March) and bacterial species. More frequently encountered bacterial strains (>19\%) are represented in bold type.

\begin{tabular}{|c|c|c|c|c|c|c|c|}
\hline \multicolumn{6}{|c|}{ Private farms } & \multicolumn{2}{|c|}{ Experimental facilities } \\
\hline $\begin{array}{l}\text { Tidal } \\
\text { areas }\end{array}$ & $\begin{array}{l}\text { Indoor } \\
\text { facilities }\end{array}$ & $\begin{array}{l}\text { Larvae } \\
\text { and } \\
\text { young } \\
\text { spat }\end{array}$ & $\begin{array}{c}\text { Juveniles } \\
\text { and } \\
\text { adults }\end{array}$ & $\begin{array}{c}\text { Cold } \\
\text { seaso } \\
n\end{array}$ & $\begin{array}{l}\text { Warm } \\
\text { season }\end{array}$ & $\begin{array}{l}\text { Larvae } \\
\text { and } \\
\text { young } \\
\text { spat }\end{array}$ & $\begin{array}{l}\text { Juveniles and } \\
\text { adults }\end{array}$ \\
\hline 48 & 15 & 29 & 34 & 5 & 58 & 32 & 20 \\
\hline $16(33 \%)$ & $4(27 \%)$ & $8(27 \%)$ & $12(25 \%)$ & 3 & $17(29 \%)$ & 6 (19\%) & $6(30 \%)$ \\
\hline $11(23 \%)$ & 1 & 0 & $12(35 \%)$ & 1 & 11 (19\%) & 2 & $11(55 \%)$ \\
\hline $6(13 \%)$ & $5(33 \%)$ & $7(24 \%)$ & $4(12 \%)$ & & 11 (19\%) & $16(50 \%)$ & 0 \\
\hline $5(10 \%)$ & $3(20 \%)$ & $5(17 \%)$ & 3 & 1 & $7(12 \%)$ & 1 & 1 \\
\hline 0 & $2(13 \%)$ & 2 & 0 & 0 & 2 & 2 & 0 \\
\hline 3 & 0 & 2 & 1 & 0 & 3 & 2 & 0 \\
\hline 3 & 0 & 2 & 1 & 0 & 3 & 0 & 0 \\
\hline 4 & 0 & 3 & 1 & 0 & 4 & 3 & $2(10 \%)$ \\
\hline
\end{tabular}




\section{Table2}

Classification of bacterial strains isolated from scallops Pecten maximus, clams Ruditapes philippinarum and abalones Haliotis tuberculata according to more frequently detected bacterial species.

\begin{tabular}{|c|c|c|c|c|c|c|}
\hline & \multirow{2}{*}{$\begin{array}{l}\text { Number of } \\
\text { batches collected } \\
\text { during mortality } \\
\text { episodes }\end{array}$} & \multirow{2}{*}{$\begin{array}{l}\text { Number } \\
\text { of strains } \\
\text { isolated }\end{array}$} & \multicolumn{4}{|c|}{ Number of bacterial strains identified } \\
\hline & & & V. splendidus & $\begin{array}{c}V . \\
\text { tapetis }\end{array}$ & V. harveyi & $\begin{array}{l}\text { Shewanella } \\
\text { colwelliana }\end{array}$ \\
\hline 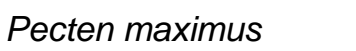 & 3 & 6 & 3 & 1 & 0 & 1 \\
\hline Ruditapes philliparum & 5 & 12 & 7 & 0 & 0 & 3 \\
\hline Haliotis tuberculata & 11 & 14 & 4 & 0 & 6 & 2 \\
\hline
\end{tabular}


Table 3

Characteristics of field isolates and Vibrio reference strains used in this study for the screening of strain virulence and proteolytic activity. Virulence of bacterial strains was evaluated by experimental infection of apparently healthy oyster spat. Column 1: Highly virulent strains, denoted "++", were defined by cumulative mortalities up to $60 \%$ after a seven day post injection survey. Avirulent strains, denoted "-", exhibited cumulative mortalities below $20 \%$ after a seven day post injection survey. Bacterial strains displaying intermediate virulence are denoted "+". Column 2: Indicates the day where the peak of mortality was recorded. Metalloprotease activity was calculated as the difference between azocaseinase activity obtained in the absence or presence of phenanthrolein. Positive metalloprotease activity was defined beyond the threshold of $50 \mathrm{u} / \mathrm{ml}$. For the majority of bacterial strains, metalloprotease activity was sensitive to phenanthrolein treatment (more than $90 \%$ of inhibition). Nevertheless, metalloprotease activity ${ }^{(1)}$ of some particular strains was partially inactivated (between $50 \%$ and $70 \%$ according to bacterial strain).

\begin{tabular}{|c|c|c|c|c|c|}
\hline Vibrio & \multirow[t]{2}{*}{ Strain } & \multirow[t]{2}{*}{ Source and context of isolation } & \multicolumn{2}{|c|}{ Virulence } & \multirow{2}{*}{$\begin{array}{l}\text { Protease } \\
\text { Metalloprotein } \\
\text { ase }\end{array}$} \\
\hline V. splendidus & & & 1 & 2 & \\
\hline V. lentus & $04 / 112$ & 2004 mortality episode(m.e) in an indoor breeding structure, Charente- & ++ & J2 & $+(61 \mathrm{u} / \mathrm{ml})$ \\
\hline V. lentus & LGP32 & C. gigas oyster spat, 2002 m.e. in Ifremer experimental facilities, La Tremblade, CM, France, & + & $\mathbf{J 2}$ & $++(120 \mathrm{u} / \mathrm{ml})$ \\
\hline V. splendidus & $03 / 028$ & C. gigas oyster spat, 2003 m.e in an indoor breeding structure, CM, France & - & & $+(64 \mathrm{u} / \mathrm{ml})$ \\
\hline V. splendidus & $03 / 013$ & R. philippinarum clam spat, 2003 m.e in an indoor breeding structure, Bouin, Vendée, France & + & J3 & $++(156 \mathrm{u} / \mathrm{ml})(1)$ \\
\hline V. & $05 / 013$ & C. gigas oyster spat, 2005 m.e. in an open sea rearing farm, Leucate lagoon, Southern France & - & & $++(141 \mathrm{u} / \mathrm{ml})$ \\
\hline V. splendidus & $05 / 103$ & P. maximus scallop spat, 2005 m.e. in an open sea rearing farm, Morlaix Bay, Brittany, France & ++ & J1 & $+++(205 \mathrm{u} / \mathrm{ml})$ \\
\hline V. splendidus & $03 / 126$ & C. gigas oyster spat, 2003 m.e. in an open sea rearing farm, Urbino lagoon, Corsica, Southern & + & $\mathrm{J5}$ & $+++(264 \mathrm{u} / \mathrm{ml})$ \\
\hline V. splendidus & $04 / 113$ & C. gigas oyster spat, 2004 m.e. in an indoor breeding structure, CM, France & ++ & J1 & $++(149 \mathrm{u} / \mathrm{ml})^{(1)}$ \\
\hline V. splendidus & $03 / 024$ & R. philippinarum clam adult, 2003 m.e. in an open sea rearing farm, Rance, Brittany, France & ++ & J1 & $+++(252 \mathrm{u} / \mathrm{ml})$ \\
\hline V. splendidus & $03 / 025$ & R. philippinarum clam adult, 2003 m.e. in an open sea rearing farm, Rance, Brittany, France & ++ & J1 & $+++(253 \mathrm{u} / \mathrm{ml})$ \\
\hline V. splendidus & $03 / 011$ & C. gigas oyster spat, 2003 m.e. in an indoor breeding structure, CM, France & - & & - (Ou/ml) \\
\hline V. splendidus & $07 / 040$ & C. gigas oyster spat, 2007 m.e. in an open sea rearing farm, Thau lagoon, Southern France & ++ & $\mathbf{J 2}$ & $++(123 \mathrm{u} / \mathrm{ml})$ \\
\hline V. splendidus & $07 / 111 \mathrm{~T} 1$ & C. gigas oyster spat, 2007 m.e. in an indoor breeding structure, CM, France & - & & $++(127 \mathrm{u} / \mathrm{ml})$ \\
\hline $\begin{array}{l}\text { V. } \\
\text { tasmaniensis }\end{array}$ & $\begin{array}{l}\text { LMG2001 } \\
2\end{array}$ & Atlantic salmon (Salmo salar L.), Tasmania, Australia, Thompson et al 2003 & - & & $-(0 \mathrm{u} / \mathrm{ml})$ \\
\hline
\end{tabular}

\section{V. harveyi group}

\begin{tabular}{|c|c|c|c|c|c|}
\hline V. harveyi & $07 / 108$ & C. gigas oyster spat, 2007 m.e. in an indoor breeding structure, CM, France & ++ & $<20$ & ++++ \\
\hline V. harveyi & $07 / 115$ T2 & C. gigas oyster spat, 2007 m.e. in an indoor breeding structure, CM, France & ++ & $<20$ & $++\quad(173 \mathrm{u} / \mathrm{ml})$ \\
\hline V. harveyi & $07 / 116$ & C. gigas oyster spat, 2007 m.e. in an indoor breeding structure, CM, France & ++ & $<20$ & $++(183 \mathrm{u} / \mathrm{ml}){ }^{(1)}$ \\
\hline V. harveyi & $07 / 118 \mathrm{~T} 2$ & C. gigas oyster spat, 2007 m.e. in an indoor breeding structure, CM, France & ++ & $<20$ & $+++(204 \mathrm{u} / \mathrm{ml})$ \\
\hline V. harveyi & $07 / 119$ & C. gigas oyster spat, 2007 m.e. in an indoor breeding structure, CM, France & ++ & $<20$ & $\ldots+(116 \mathrm{u} / \mathrm{ml})$ \\
\hline V. harveyi & $07 / 121$ & C. gigas oyster spat, 2007 m.e. in an indoor breeding structure, CM, France & ++ & $<20$ & $++(185 \mathrm{u} / \mathrm{ml})^{(1)}$ \\
\hline V. harveyi & $03 / 082$ & C. gigas oyster spat, 2003 m.e. in an open sea rearing farm, Thau lagoon, Southern France & + & J1 & - (3u/ml) \\
\hline V. harveyi & $04 / 002$ & H. tuberculata spat, 2004 m.e. in a hatchery, Normandy, France & ++ & $<20$ & $++(137 \mathrm{u} / \mathrm{ml})$ \\
\hline V. harveyi & $04 / 107$ & H. tuberculata juvenile, 2004 m.e. in an indoor breeding structure, Blainville-sur-Mer & ++ & $\mathrm{J} 2$ & - (12 u/ml) \\
\hline V. & $05 / 091$ & C. gigas oyster spat, 2005 m.e. in an indoor breeding structure, CM, France, Sau & ++ & $\mathbf{J 2}$ & $+(85 \mathrm{u} / \mathrm{ml})$ \\
\hline
\end{tabular}




\begin{tabular}{|c|c|c|c|c|c|}
\hline V. & $04 / 021$ & C. gigas oyster spat, 2004 m.e. in an indoor breeding structure, CM, France, Saulnier et al, & ++ & J3 & ++ (185 u/ml) \\
\hline V. & $04 / 047$ & C. gigas oyster spat, 2004 m.e. in an indoor breeding structure, CM, France, Saulnier et al, & ++ & $\mathrm{J5}$ & $+++(209 \mathrm{u} / \mathrm{ml})$ \\
\hline V. & $03 / 011$ & C. gigas oyster spat, 2003 m.e. in an indoor breeding structure, CM, France, Saulnier et al, & ++ & J3 & $++(120 \mathrm{u} / \mathrm{ml}))$ \\
\hline V. & $03 / 146$ & C. gigas oyster adult, 2003 m.e. in an open sea rearing farm, Angoulin, CM, France, Saulnier et & ++ & J3 & $++(172 \mathrm{u} / \mathrm{ml})$ \\
\hline V. & $04 / 055$ & C. gigas oyster adult, 2004 m.e. in an open sea rearing farm, Arcachon Bay, Gironde, France, & ++ & J3 & $+(96 \mathrm{u} / \mathrm{ml})$ \\
\hline V. & $07 / 083$ & C. gigas oyster adult, 2007 m.e. in an open sea rearing farm, Marennes-Oléron Bay, CM, & ++ & $\mathrm{J3}$ & $++(189 \mathrm{u} / \mathrm{ml})$ \\
\hline V. & $07 / 046$ & C. gigas oyster adult, 2007 m.e. in an open sea rearing farm, Olonne, Vendée, France, Saulnier & ++ & $\mathbf{j} 2$ & $++(183 \mathrm{u} / \mathrm{ml})$ \\
\hline V. & $07 / 080$ & C. gigas oyster adult, 2007 m.e. in an open sea rearing farm, Marennes-Oléron Bay, CM, & ++ & $\mathrm{J} 2$ & $+(83 \mathrm{u} / \mathrm{ml})$ \\
\hline V. & $02 / 041$ & C. gigas oyster adult, 2002 m.e. in a hatchery, Argenton, Finistère, France, Garnier et al 2007 & ++ & $\mathrm{J} 2$ & $++(173 \mathrm{u} / \mathrm{ml})$ \\
\hline S. & $07 / 050$ & C. gigas oyster spat, 2007 m.e. in an open sea rearing farm, Bay of Morbihan, Brittany, France & - & & $-(7 \mathrm{u} / \mathrm{ml})$ \\
\hline S. & $07 / 079$ & C. gigas oyster adult, 2007 m.e. in an open sea rearing farm, Marennes-Oléron Bay, CM, & - & & - (12 u/ml) \\
\hline S. & 07/082 T2 & C. gigas oyster spat, 2007 m.e. in a hatchery, Bourgneuf Bay, Vendée, France & + & $\mathrm{J} 2$ & - (8u/ml) \\
\hline S. & $07 / 085$ & C. gigas oyster spat, 2007 m.e. in a hatchery, Bourgneuf Bay, Vendée, France & - & & - (23 u/ml) \\
\hline S. & $07 / 086$ & C. gigas oyster spat, 2007 m.e. in a hatchery, Bourgneuf Bay, Vendée, France & - & & - (32 u/ml) \\
\hline
\end{tabular}


Table 4

Contingency table showing the number of bacterial strains characterized according their ability to produce metalloprotease-like enzyme or not in culture supernants, given with their virulence status evaluated by experimental infection (See table 3).

Metalloprotease-like activity

\begin{tabular}{|c|c|c|c|c|}
\hline \multirow{3}{*}{$\begin{array}{c}\text { Virulence } \\
\text { status }\end{array}$} & & + & - & \multirow{3}{*}{$\begin{array}{l}76 \% \\
24 \%\end{array}$} \\
\hline & + & $26(90 \%)$ & 3 & \\
\hline & - & $3(10 \%)$ & 6 & \\
\hline & & $76 \%$ & $24 \%$ & \\
\hline
\end{tabular}

\section{Figures}




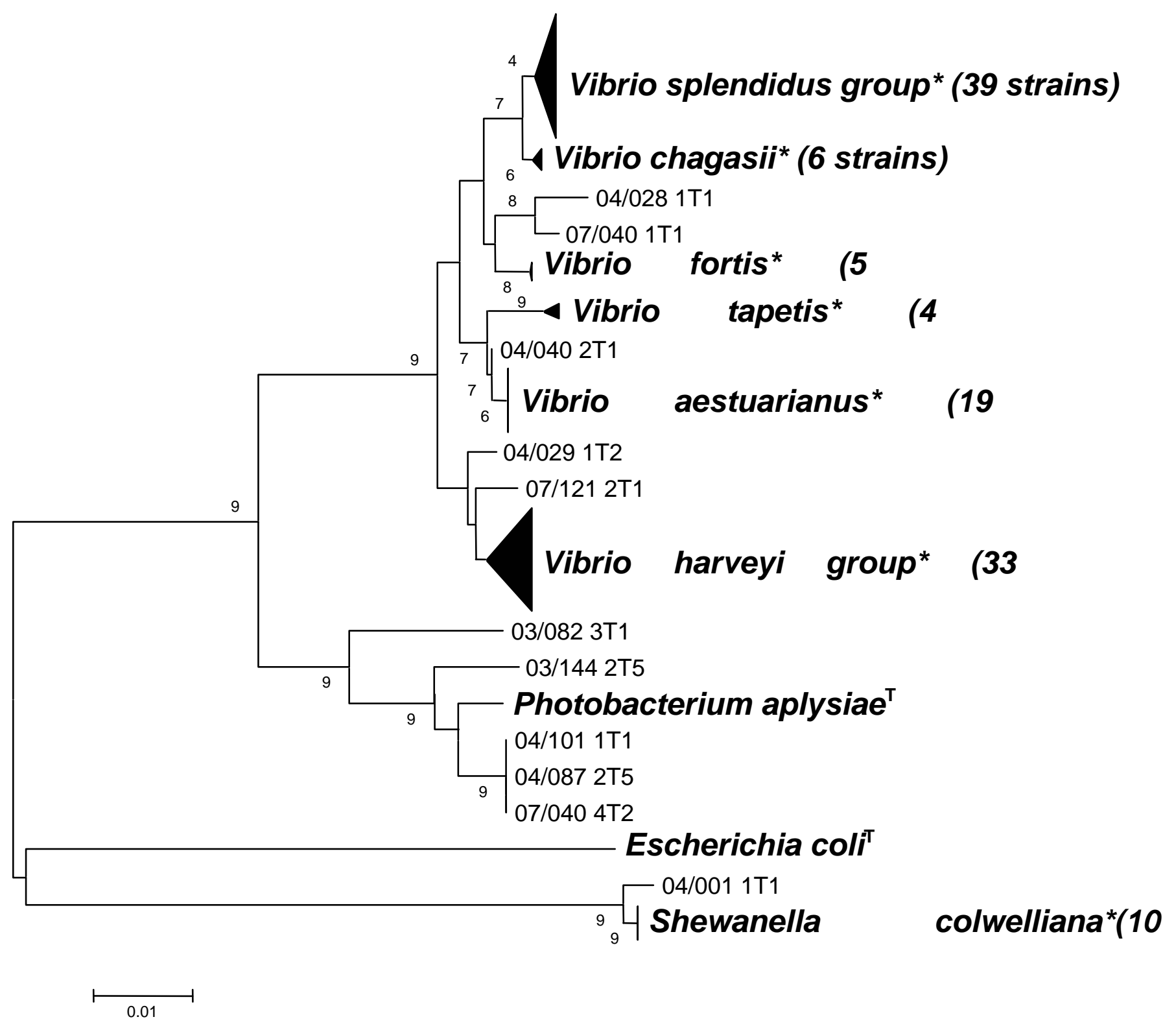

Figure 1

Phylogenetic tree of partial 16S rDNA from bacteria isolated from 4 cultivated mollusc species (mainly C. gigas), collected in the context of mortalities (92 episodes), and Vibrio reference strains. A total of 652 gap-free sites were analysed. The evolutionary distances were computed using the Neighbour-Joining method. Bootstrap values (1000 replicates) greater than $50 \%$ are indicated.* denotes a reference type strain that was included to identify the strains of this study. 


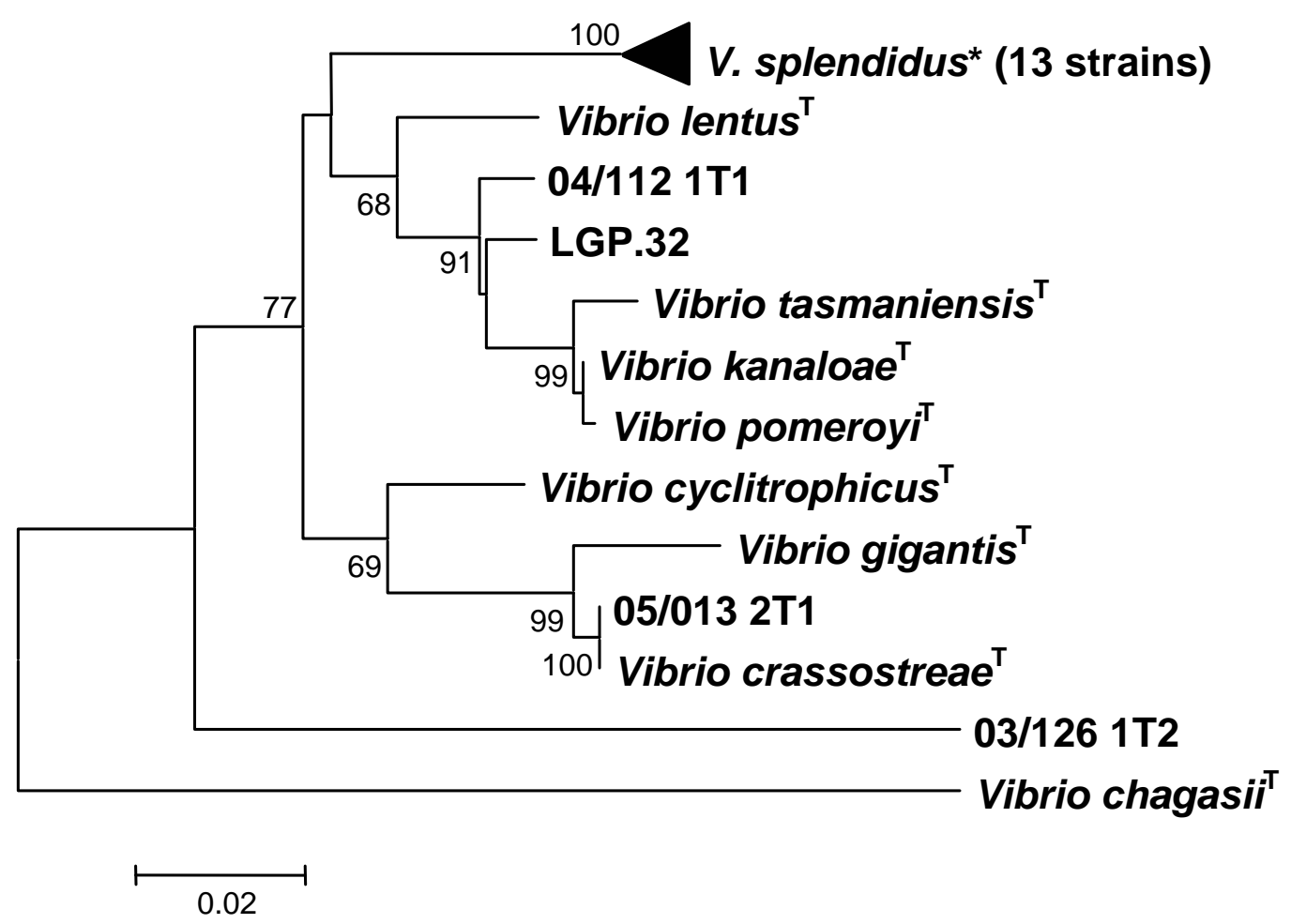

Figure 2

Phylogenetic tree of partial gyrB gene from bacteria isolated from 3 bivalve mollusc species collected in a context of mortalities (19 episodes) and reference Vibrio strains, based on the analysis of 700 gap-free sites. The evolutionary distances were computed using Neighbour-Joining method and Kimura 2 parameter model. Bootstrap values (1000 replicates) greater than $50 \%$ are indicated. * denotes a reference type strain that was included to identify the strains of this study. 


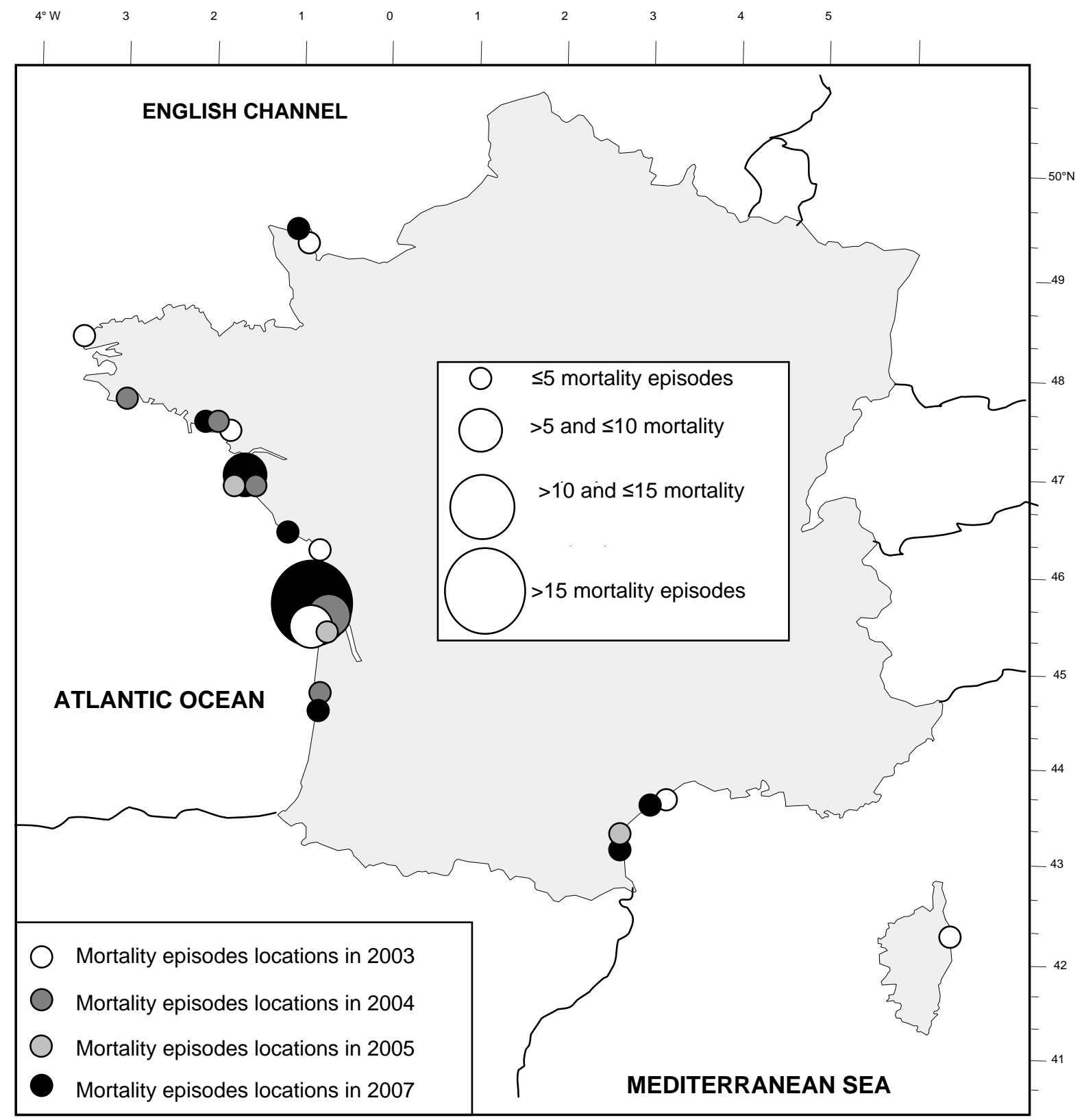

\section{Figure 3}

Distribution of the 73 C. gigas mortality episodes between 2003 and 2007 in both private farms and Ifremer experimental facilities. 
Cumulative mortalities (\%) 5 days post infection

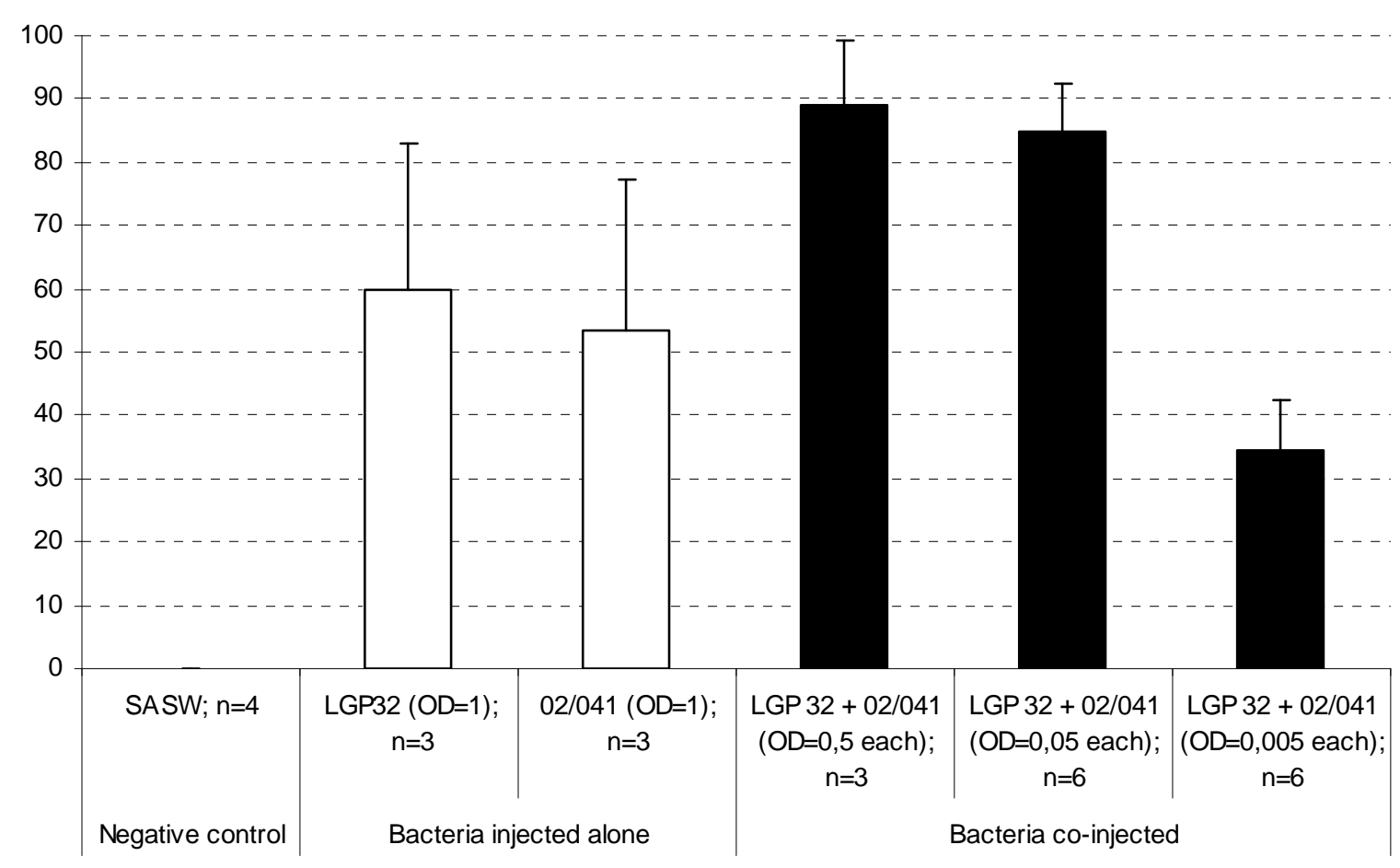

\section{Figure 4}

Cumulative mortality rates (\%) at day five post injection with bacterial strains. Strains LGP32 (V. splendidus) and 02/041 (V. aestuarianus) were injected individually using a bacterial suspension at $O D=1$. The same strains were injected as a mixture and at different doses. Sterile artificial seawater (SASW) was used as negative control. Fifteen to twenty injected oysters were placed in each aquarium. Symbol "n" indicates the number of aquaria or replicates; bars show standard deviations. 